\title{
Influence of Living and Autoclaved Yeasts of Saccharomyces boulardii on In Vitro Ruminal Microbial Metabolism
}

\author{
H. Oeztuerk, ${ }^{1}$ B. Schroeder, ${ }^{2}$ M. Beyerbach, ${ }^{3}$ and $\mathrm{G}$. Breves $^{2}$ \\ ${ }^{1}$ Department of Physiology, Faculty of Veterinary Medicine, University of Ankara 06110 Ankara, Turkey \\ ${ }^{2}$ Department of Physiology, and \\ ${ }^{3}$ Department of Biometry, Epidemiology and Information Processing School of Veterinary Medicine, \\ Hannover, Germany
}

\begin{abstract}
Experimental data on the effects of Saccharomyces boulardii on rumen microbial metabolism are scarce. The aim of this study was to examine whether S. boulardii had an effect on parameters of rumen microbial metabolism at different dosages and whether the yeast would be suitable as a probiotic agent for ruminants. To test whether the potential positive effects of $S$. boulardii could be attributed to the yeast's viability or to its content of nutrients, living and autoclaved yeasts were tested simultaneously. For this purpose, incubation trials were carried out using the long-term rumen simulation technique. Living and autoclaved yeasts were added to fermentation vessels at a concentration of 0.5 or $1.5 \mathrm{~g} / \mathrm{d}$. The addition of living and autoclaved yeasts stimulated microbial metabolism, with no major differences between the treatments. It was concluded that ruminal microbes digested the supplied yeast of $S$. boulardii as an additional substrate and that $S$. boulardii, at least in ruminants, is utilized as a prebiotic rather than as a probiotic agent.
\end{abstract}

(Key words: Saccharomyces boulardii, yeast, ruminal microbial metabolism)

Abbreviation key: SCFA = short-chain fatty acids .

\section{INTRODUCTION}

Dietary supplements of yeast cultures, based on freeze-dried Saccharomyces cerevisiae, have been reported to improve health and productivity of ruminants. In comparison with antimicrobial agents, yeast cultures offer a natural alternative to manipulate animal performance. They have been shown to improve feed intake (Phillips and von Tungeln, 1985; Harris and Lobo, 1988; Williams et al., 1991), milk production (Harris and Webb, 1990; Piva et al., 1993; Kung et al., 1997; Dann

Received July 28, 2004.

Accepted January 31, 2005.

Corresponding author: Gerhard Breves; e-mail: gerhard.breves@ tiho-hannover.de. et al., 2000), and weight gain (Phillips and von Tungeln, 1985; Fallon and Harte, 1987; Hughes, 1988; Drennan, 1990). However, yeast cultures have not been found to alter ruminal metabolism or improve animal performance in all cases (Adams et al., 1981; Harrison et al., 1987; Arambel and Kent, 1990; Chademana and Offer, 1990; Williams et al., 1991; Cabrera et al., 2000; Garcia et al., 2000). Some of the reasons for these inconsistencies may be strain-dependent (Newman and Spring, 1993; Newbold et al., 1995), or due to specific differences between commercial additives (Arcos-García et al., 2000; Miller-Webster et al., 2002), or mediated by differences in dietary compositions (Fiems et al., 1993; Wallace, 1994; Adams et al., 1995). More than 1000 strains of $S$. cerevisiae are listed in the American Type Culture Collection catalogue (ATCC, 1990) and it is still not known how widespread the so-called probiotic activity is among these strains of yeast. It has been observed that different strains of Saccharomyces cerevisiae had distinct effects on rumen bacteria under in vitro conditions and in in vivo experiments with sheep (Newbold et al., 1995). Saccharomyces boulardii is a nonpathogenic yeast that was originally used in humans to prevent or treat diarrhea of various origins (Czerucka and Rampal, 2002). In addition, it has been shown in recent in vitro experiments in Ussing chambers with mucosal tissues from the mid-jejunum of pigs that prophylactic treatment of the animals with $S$. boulardii can significantly diminish an artificially induced secretory response of the jejunal mucosa due to application of theophylline (Schroeder et al., 2004). Theophylline increases intracellular cyclic nucleotide levels, which can stimulate mucosal $\mathrm{Cl}^{-}$secretion. Lowering this effect, as seen with $S$. boulardii, at least supports the concept that probiotics may exert beneficial effects in the gastrointestinal tract.

In contrast, the effects of $S$. boulardii on ruminal microbial metabolism have not yet been investigated. It was the aim of this study to investigate potential positive effects of this strain on short-chain fatty acid (SCFA) production rates, protein synthesis, and digestibility of organic matter. We specifically addressed the 
Table 1. Chemical compositions of the diets (\%).

\begin{tabular}{lcc}
\hline Ingredient & Hay & Concentrate \\
\hline DM & 93.94 & 90.48 \\
CP & 7.27 & 15.96 \\
Crude lipids & 0.88 & 2.32 \\
Crude fiber & 27.59 & 10.49 \\
N-free extract & 46.01 & 43.46 \\
Total ash & 6.13 & 8.83 \\
\hline
\end{tabular}

question of whether the effects of $S$. boulardii required viable probiotic yeasts or would also be observed with the autoclaved (prebiotic) form.

\section{MATERIALS AND METHODS}

\section{Incubation Technique}

The study was carried out using the rumen simulation technique (RUSITEC; Czerkawski and Breckenridge, 1977). The experiment consisted of 9 plexiglass 1 -L vessels (fermentors) maintained at constant temperature $\left(39^{\circ} \mathrm{C}\right)$. The nominal volume in each vessel was $750 \mathrm{~mL}$. The vessels were inoculated on $\mathrm{d} 1$ with liquid (gauze-filtered) and solid rumen contents taken from 2 rumen cannulated adult donor sheep that were maintained on a diet of hay and concentrates. Animals had free access to hay, water, and a vitamin-enriched salt lick. The same dietary components were used for in vitro fermentation trials. The chemical composition is presented in Table 1. Each vessel was loaded with 2 nylon bags (pore size, $150 \mu \mathrm{m}$ ). At the start of the trial, one bag was filled with $80 \mathrm{~g}$ of solid rumen contents (fresh weight) and the other with the daily diet, a mixture of $5 \mathrm{~g}$ of hay and $4 \mathrm{~g}$ of pelleted concentrate. The nylon bag with solid rumen contents was replaced after $24 \mathrm{~h}$ of incubation with a bag containing the diet. The feed bag was changed after $48 \mathrm{~h}$ so that 2 bags were always present. This gave a retention time of $48 \mathrm{~h}$ for feed. When the bag was being changed, the vessels were flushed with nitrogen to maintain anaerobic conditions. The liquid flow through the vessels was maintained by continuous infusion of a buffer solution of $\mathrm{pH} 7.4$ with $293 \mathrm{mosm} / \mathrm{L}$ at a rate of $750 \mathrm{~mL} / \mathrm{d}$. The buffer composition is presented in Table 2. Starting with the collection

Table 2. Chemical composition of the buffer solution (mmol/L).

\begin{tabular}{|c|c|}
\hline \multicolumn{2}{|l|}{ Ingredient } \\
\hline $\mathrm{NaCl}$ & 28.00 \\
\hline $\mathrm{KCl}$ & 7.69 \\
\hline $\mathrm{CaCl}_{2} \cdot 2 \mathrm{H}_{2} \mathrm{O}$ & 0.22 \\
\hline $\mathrm{MgCl}_{2} \cdot 6 \mathrm{H}_{2} \mathrm{O}$ & 0.63 \\
\hline $\mathrm{NH}_{4} \mathrm{Cl}$ & 5.00 \\
\hline${ }^{15} \mathrm{NH}_{4} \mathrm{Cl}$ & 0.07 \\
\hline $\mathrm{Na}_{2} \mathrm{HPO}_{4} \cdot 12 \mathrm{H}_{2} \mathrm{O}$ & 10.00 \\
\hline $\mathrm{NaH}_{2} \mathrm{PO}_{4} \cdot \mathrm{H}_{2} \mathrm{O}$ & 10.00 \\
\hline $\mathrm{NaHCO}_{3}$ & 97.90 \\
\hline
\end{tabular}

period, a solution of ${ }^{15} \mathrm{NH}_{4} \mathrm{Cl}\left(98 \%\right.$ excess ${ }^{15} \mathrm{~N}$, Promochem, Wesel, Germany) was added to the buffer solution as a marker for calculating net microbial protein synthesis.

\section{Experimental Procedure}

To examine the role of living and autoclaved S. boulardii, 4 experiments were performed; each experiment lasted for $16 \mathrm{~d}$. The first 8-d period represented an adaptation period (to achieve steady state conditions) and was followed by an 8-d collection period. At the start of the collection period, living or autoclaved yeasts of Saccharomyces cerevisiae Hansen CBS 5926 (Hexal AG, Holzkirchen, Germany) were added to the respective fermentation vessels. The product was delivered in lyophilized form containing at least $2 \times 10^{10} \mathrm{cfu} / \mathrm{g}$. During the collection period of experiment 1 , the 9 vessels were divided into 3 groups. One group served as controls; 0.5 and $1.5 \mathrm{~g} / \mathrm{d}$ of living yeast was added to the second and third group, respectively. This experimental setup was repeated in experiment 3 . Experiments 2 and 4 were performed under the same conditions as the others, except that autoclaved yeast was used. The following considerations were the basis for the chosen yeast dosages. With respect to the literature, inclusion rates in the diet are typically in the range of 4 to $100 \mathrm{~g} /$ $\mathrm{d}$ (Newbold, 1995). As described, the fermentor content was $750 \mathrm{~mL}$ to which 0.5 or $1.5 \mathrm{~g}$ of $S$. boulardii was added per d. Extrapolating these values to the in vivo condition of sheep rumen liquid content $(10 \mathrm{~L})$, this would result in 6.7 or $20 \mathrm{~g}$ of $S$. boulardii given to the animal, respectively.

Inactivation of $S$. boulardii was achieved by autoclave standard operating procedures $\left(213 \mathrm{kPa}\right.$ at $121^{\circ} \mathrm{C}$ for $20 \mathrm{~min}$ ). To test if the inactivation was complete, $10 \mathrm{mg}$ of autoclaved yeasts were incubated at $30^{\circ} \mathrm{C}$ in yeast extract/peptone/dextrose liquid medium (Serva, Heidelberg, Germany) in a shaking incubator (GFL shaking inkubator 3031, Burgwedel, Germany) at 200 $\mathrm{rpm}$ for $16 \mathrm{~h}$. Then, $100 \mu \mathrm{L}$ of inoculate the liquid medium was plated onto yeast extract/peptone/dextrose agar, and incubated for $3 \mathrm{~d}$ at $30^{\circ} \mathrm{C}$. No living yeasts were detected.

\section{Analytical Procedures and Samplings}

The $\mathrm{pH}$ values and redox potentials were measured daily in each vessel at the time of feeding using a $\mathrm{pH}$ electrode (Typ 408 and Pt 4805-S7/120, Mettler Toledo, Steinbach, Germany) connected to a Knick $\mathrm{pH}$ meter (digital pH meter 646, Knick, Berlin, Germany). Liquid effluent was collected daily and samples were taken for analyses of SCFA, $\mathrm{NH}_{3}-\mathrm{N}$, and ${ }^{15} \mathrm{~N}$ enrichments. The 
overflow flasks were placed into ice to stop microbial activity and preserve fermentation products. An aliquot of effluent was centrifuged at $40,000 \times \mathrm{g}$ for $20 \mathrm{~min}$ at $4^{\circ} \mathrm{C}$. The resulting supernatant was acidified with 0.1 $\mathrm{mL}$ of $98 \%$ formic acid and then centrifuged at $4000 \times$ $\mathrm{g}$ for $10 \mathrm{~min}$ at $4^{\circ} \mathrm{C}$. The supernatant was analyzed for SCFA by gas chromatography (model 5890 II, Hewlett Packard, Böblingen, Germany) equipped with a $1.8 \mathrm{~m}$ $\times 2 \mathrm{~mm}$ glass column packed with Chromosorb WAW (mesh 80/100) with 20\% neopentyl glycol succinate and $2 \%$ ortho phosphoric acid. Helium was used as a carrier gas with a flow rate of $25 \mathrm{~mL} / \mathrm{min}$. Injection port, detector, and oven temperatures were 220,250 , and $130^{\circ} \mathrm{C}$, respectively. Daily production rates of SCFA were estimated by multiplying the respective concentration by the volume of effluent collected. Ammonia $\mathrm{N}$ was measured using the steam distillation method of Kjeldahl (Stuck et al., 1995). Bacterial fractions were isolated from respective effluents using differential centifugation according to the method of Brandt and Rohr (1981). Enrichment of ${ }^{15} \mathrm{~N}$ was analyzed by ${ }^{15} \mathrm{~N}$ emission spectrometry (NOI-7, Fischer Analysen Instrumente, Leip- zig, Germany) in $\mathrm{NH}_{3}-\mathrm{N}$ fractions of the infusion buffer, the effluents, and bacterial fractions at $\mathrm{d} 6$ to 8 . At these times, the steady state conditions were reached for ${ }^{15} \mathrm{~N}$ enrichment in the microbial cell mass. The daily production of microbial $\mathrm{N}$ was calculated by the equation of Nolan and Leng (1983). This value was multiplied by 6.25 to calculate microbial protein synthesis.

\section{Statistical Analyses}

Because the number of fermentation vessels was limited, the experiments were divided into 4 consecutive trials in a mixed sequence (living/autoclaved/living/autoclaved yeasts). To rule out potential time-dependent differences between trials, we used identical liquid and solid rumen contents sampled and mixed from the same 2 donor sheep in each experiment. All other technical applications remained unchanged. Therefore, it seemed appropriate to treat the data as randomized across the experimental period. The results from $d 1,5$, and 8 , and the results of the microbial protein synthesis from

Table 3. Results of 2-way ANOVA of the factors dose and status at different days of Saccharomyces boulardii application.

\begin{tabular}{|c|c|c|c|c|}
\hline $\begin{array}{l}\text { Parameters of microbial } \\
\text { metabolism }\end{array}$ & Day of application & Dose of additive ${ }^{1}$ & Status of yeast ${ }^{2}$ & $\begin{array}{l}\text { Interaction } \\
\text { dose } \times \text { status }\end{array}$ \\
\hline \multirow[t]{3}{*}{$\mathrm{pH}$} & 1 & $* *$ & NS & NS \\
\hline & 5 & NS & NS & NS \\
\hline & 8 & NS & NS & NS \\
\hline \multirow[t]{3}{*}{ Redox potential } & 1 & NS & NS & NS \\
\hline & 5 & NS & NS & NS \\
\hline & 8 & NS & NS & NS \\
\hline \multirow[t]{3}{*}{ Total short-chain fatty acids } & 1 & NS & NS & NS \\
\hline & 5 & $* * *$ & NS & NS \\
\hline & 8 & $* * *$ & NS & NS \\
\hline \multirow[t]{3}{*}{ Acetate } & 1 & NS & NS & NS \\
\hline & 5 & $* * *$ & NS & NS \\
\hline & 8 & $*$ & NS & NS \\
\hline \multirow[t]{3}{*}{ Propionate } & 1 & NS & NS & NS \\
\hline & 5 & $*$ & NS & NS \\
\hline & 8 & NS & NS & NS \\
\hline \multirow{3}{*}{ Butyrate } & 1 & $*$ & NS & NS \\
\hline & 5 & $* * *$ & $*$ & NS \\
\hline & 8 & $* * *$ & $*$ & NS \\
\hline \multirow[t]{3}{*}{ Isovalerate } & 1 & $* * *$ & $*$ & NS \\
\hline & 5 & $* * *$ & $* * *$ & $* * *$ \\
\hline & 8 & $* * *$ & $* * *$ & $* * *$ \\
\hline \multirow[t]{3}{*}{ Valerate } & 1 & NS & NS & NS \\
\hline & 5 & $* * *$ & NS & NS \\
\hline & 8 & $* * *$ & NS & NS \\
\hline \multirow[t]{3}{*}{$\mathrm{NH}_{3}-\mathrm{N}$} & 1 & $* * *$ & NS & NS \\
\hline & 5 & $* * *$ & $* *$ & NS \\
\hline & 8 & $* * *$ & $*$ & NS \\
\hline \multirow[t]{3}{*}{ Microbial protein } & 6 & $* * *$ & NS & NS \\
\hline & 7 & $* * *$ & $* * *$ & NS \\
\hline & 8 & $* * *$ & $* *$ & NS \\
\hline
\end{tabular}

\footnotetext{
${ }^{1}$ Dose $=$ addition of $0,0.5$, or $1.5 \mathrm{~g} / \mathrm{d}$ of Saccharomyces boulardii.

${ }^{2}$ Status of yeast $=$ living or autoclaved.

$* P \leq 0.05 ; * * P \leq 0.01 ; * * * P \leq 0.001$; NS $P>0.05$.
} 


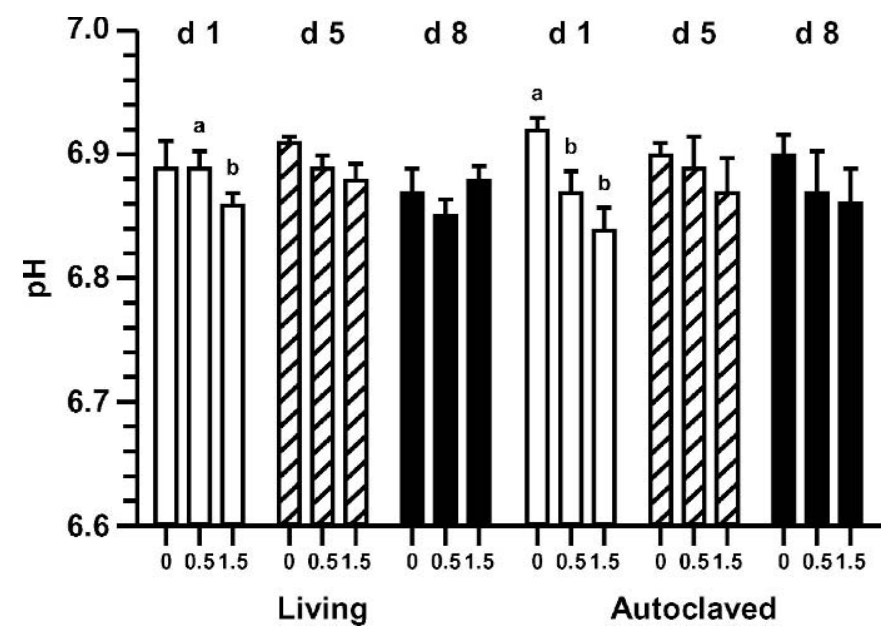

Figure 1. $\mathrm{pH}$ values as affected by increasing dose $(0,1.0$, and $1.5 \mathrm{~g} / \mathrm{d}$ ) of living or autoclaved Saccharomyces boulardii at d 1, 5, and 8 after beginning of application (mean \pm SEM, $n=6$; different lowercase superscripts on a given day represent significant effects of dose with at least $P \leq 0.05$ ).

d 6,7 , and 8 were statistically evaluated by 2 -way ANOVA using the GraphPad Prism version 4.00 for Windows (GraphPad Software, San Diego, CA; www.graphpad.com). Effects included in the model were dose of yeast $(0,0.5$, and $1.5 \mathrm{~g})$ and status (living or autoclaved). In case of a significant result for the effects of dose of $S$. boulardii and status of $S$. boulardii, individual mean values were checked in pairs using a 2-tailed t-test for unpaired observations.

\section{RESULTS AND DISCUSSION}

\section{pH Values and Redox Potentials}

Throughout the experiment, $\mathrm{pH}$ values ranged between 6.82 and 6.92 and were thus within the physiological range of rumen fluid $\mathrm{pH}$. Irrespective of the type of additive at $\mathrm{d} 1, \mathrm{pH}$ values showed a significant dosedependent decrease after yeast application (Table 3, Figure 1). This might be explained by adaptation of rumen microbes to the new conditions. However, it must also be considered that the overall $\mathrm{pH}$ differences were rather low and this most probably rules out a significant biological importance of this effect. It is generally accepted that redox potentials can serve as a measure of the anaerobic conditions in the rumen (Broberg, 1957; Mishra et al., 1970). If a range between -250 and $-350 \mathrm{mV}$ is assumed for physiological conditions in the rumen, all data obtained from the present study are well within this range (Figure 2). There was no statistically significant effect of the additives. This observation is consistent with the almost unaffected $\mathrm{pH}$ values.

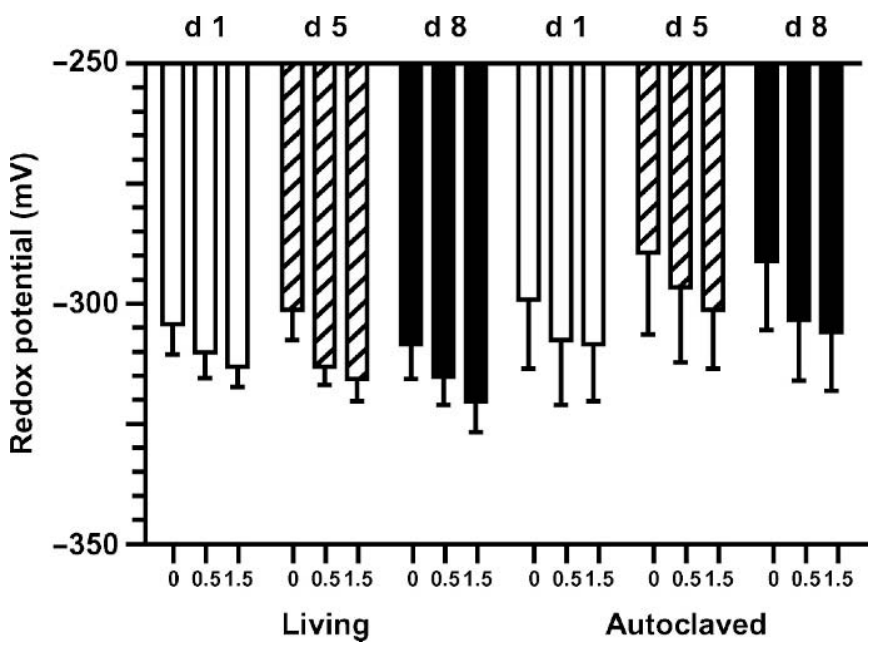

Figure 2. Redox potentials as affected by increasing dose $(0,1.0$, and $1.5 \mathrm{~g} / \mathrm{d}$ ) of living or autoclaved Saccharomyces boulardii at d 1, 5 , and 8 after beginning of application (mean \pm SEM, $\mathrm{n}=6$ ).

\section{SCFA}

Irrespective of $S$. boulardii status, total SCFA production was significantly increased in a dose-dependent manner at d 5 and 8 (Table 3, Figure 3a). This was mainly due to respective changes in acetate production rates (Figure $3 b$ ). In contrast, propionate production showed no significant differences in response to either living or autoclaved $S$. boulardii (Figure 3c). On the other hand, the addition of both yeasts increased the production rates of butyrate, isovalerate, and valerate at $\mathrm{d} 5$ and 8 (Table 3, Figure 3, parts d, e, and f). At d 5 and a dosage of $1.5 \mathrm{~g}$, the stimulatory effect on butyrate production was higher in the presence of autoclaved yeasts than with living yeasts. A potential explanation for the stimulatory effects of yeasts or yeast products on SCFA production could be related to the composition of the cell wall or other cell contents of $S$. boulardii. The cell wall comprises 3 components, namely glucans, mannoproteins, and chitin, and represents $20 \%$ of the dry weight of the cell. It consists of a layered structure, with an internal layer made up of $\beta-1,3$ and $\beta-1,6$ glucans, as well as small amounts of chitin and mannoproteins, and an outer layer of mannoproteins (Fleet, 1991; Klis, 1994; Moukadiri et al., 1997). These structures are appropriate substrates for microbial fermentation in the rumen irrespective of the yeast status.

The production of isovalerate formed the most remarkable difference between living and autoclaved yeasts because the increased production by living yeasts was significantly higher than by autoclaved yeasts. In the presence of living yeasts, the molar proportion of isovalerate increased from approximately 1 to $5 \%$. This increase is probably based on the production 

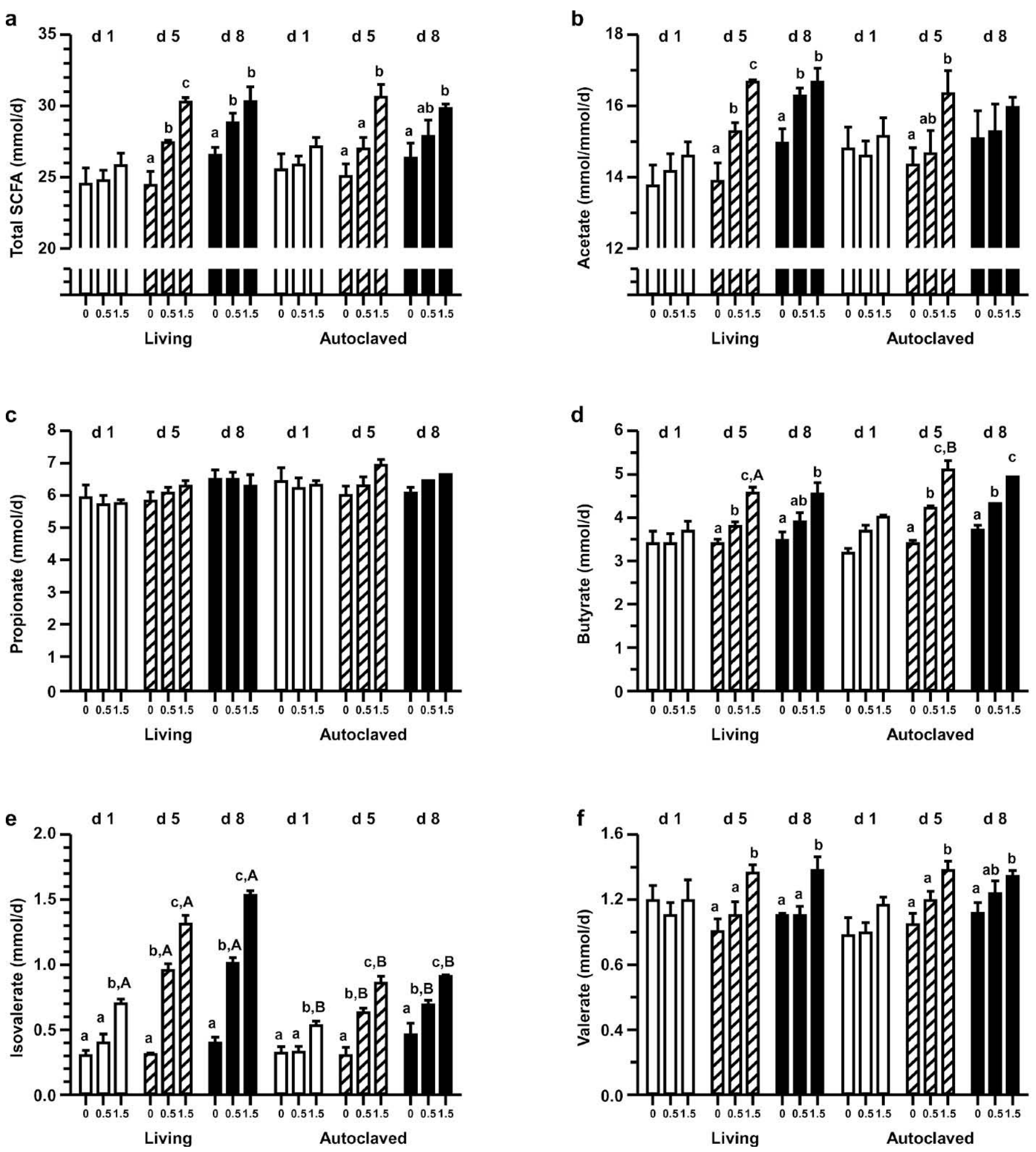

Figure 3. Daily total short-chain fatty acids (a), acetate (b), propionate (c), butyrate (d), isovalerate (e), and valerate (f) production as affected by increasing dose (0,1.0, and $1.5 \mathrm{~g} / \mathrm{d})$ of living or autoclaved Saccharomyces boulardii at d 1, 5 and 8 after beginning of application. (mean \pm SEM, $\mathrm{n}=6$; different lowercase superscripts on a given day represent significant effects of dose with at least $P \leq 0.05$, different uppercase superscripts at a given concentration represent significant effects of $S$. boulardii status with at least $P \leq 0.05$ ). 


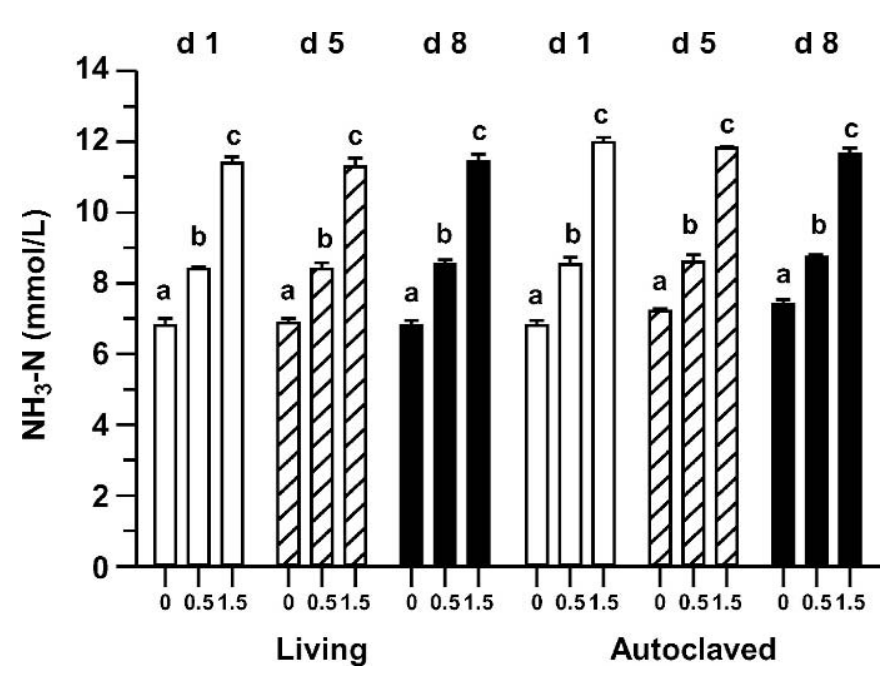

Figure 4. Daily $\mathrm{NH}_{3}-\mathrm{N}$ production as affected by increasing dose $(0,1.0$, and $1.5 \mathrm{~g} / \mathrm{d})$ of living or autoclaved Saccharomyces boulardii at $\mathrm{d} 1,5$, and 8 after beginning of application (mean $\pm \mathrm{SEM}, \mathrm{n}=6$; different lowercase superscripts on a given day represent significant effects of dose with at least $P \leq 0.05$ ).

of ethanol. Ethanol may be converted by ruminal microorganisms into acetate and into isovalerate, which was shown by studies with $2-{ }^{14} \mathrm{C}$ ethanol and by feeding experiments with ethanol (Orskov and Hemken, 1967; Pradhan and Hemken, 1970).

\section{$\mathrm{NH}_{3}-\mathrm{N}$ and Microbial Protein Synthesis}

Regardless of additive type, NH3-N concentrations were characterized by dose-dependent differences during the experimental period (Table 3, Figure 4). Whereas the average $\mathrm{NH}_{3}-\mathrm{N}$ concentrations ranged around $7 \mathrm{mmol} / \mathrm{L}$ in all control vessels, the application of $0.5 \mathrm{~g}$ of $S$. boulardii per d increased the $\mathrm{NH}_{3}-\mathrm{N}$ concentrations to $8.5 \mathrm{mmol} / \mathrm{L}$. They were further increased to about $12 \mathrm{mmol} / \mathrm{L}$ at a dosage of $1.5 \mathrm{~g} / \mathrm{d}$ of $S$. boulardii. The chemical composition of the yeast has to be discussed as a major factor for these differences. Respective analyses have shown that $\mathrm{CP}$ contents of $S$. boulardii ranged around 39\% (G. Breves, unpublished data, 2003). Thus, substantial increases in $\mathrm{NH}_{3}-\mathrm{N}$ concentrations will occur in response to microbial degradation of yeast cells, which does not depend on $S$. boulardii status.

Similar changes as for NH3-N concentrations were recorded for microbial protein synthesis as measured at $\mathrm{d} 6,7$, and 8 after reaching steady state enrichment of ${ }^{15} \mathrm{~N}$ in microbial cell mass. At each sampling day, the application of 0.5 or $1.5 \mathrm{~g} / \mathrm{d}$ of $S$. boulardii (except autoclaved yeast on d 6 ) resulted in significantly higher values for microbial protein synthesis compared with control vessels irrespective of type of $S$. boulardii (Fig-

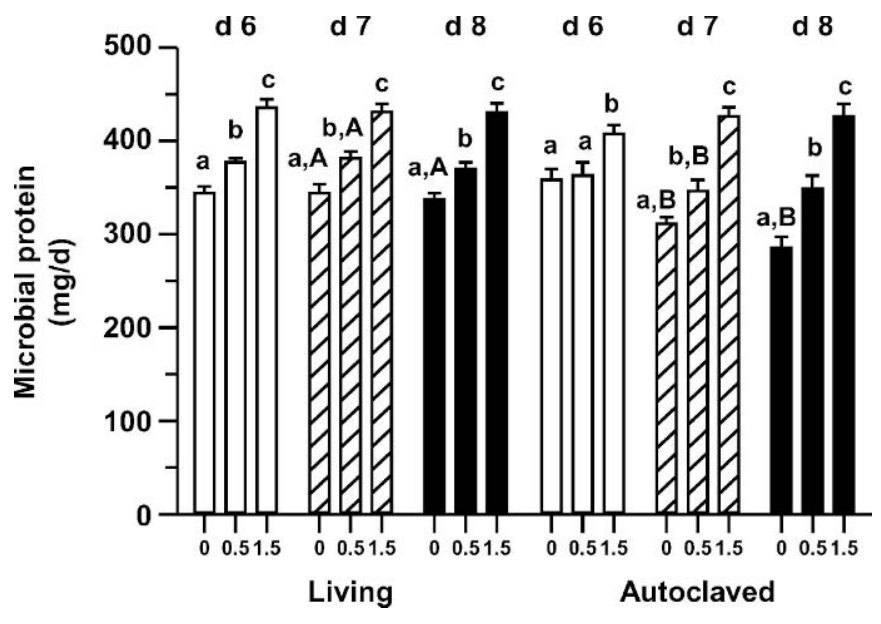

Figure 5. Daily microbial protein production as affected by increasing dose $(0,1.0$, and $1.5 \mathrm{~g} / \mathrm{d})$ of living or autoclaved Saccharomyces boulardii at $\mathrm{d} 6,7$, and 8 after beginning of application (mean \pm $\mathrm{SEM}, \mathrm{n}=6$; different lowercase superscripts on a given day represent significant effects of dose with at least $P \leq 0.05$; different uppercase superscripts at a given concentration represent significant effects of $S$. boulardii status with at least $P \leq 0.05$ ).

ure 5). In a few cases at $d 7$ and 8 and at dosages of 0 to $0.5 \mathrm{~g} / \mathrm{d}$ of $S$. boulardii, living yeasts lead to significantly higher values for microbial protein synthesis than did the application of autoclaved yeasts. This observation cannot be explained, but it seems unlikely that this effect was $S$. boulardii-dependent because it also occurred in the absence of additives. In summary, the latter data are not in accordance with assumptions that the stimulatory effects of yeasts on rumen microbial growth depend on living yeasts (Dawson et al., 1990; Kumar et al., 1994; Newbold et al., 1998). The reasons for this discrepancy are not yet fully understood. It cannot be excluded that stimulatory factors for microbial growth are released when yeast cells are microbially degraded.

\section{CONCLUSIONS}

The aim of the present study was to measure the effects of living and autoclaved $S$. boulardii on major biochemical parameters of rumen microbial metabolism. Through the application of yeasts, rumen microbial metabolism was stimulated. For most parameters, no advantages of living yeasts could be detected and from this it may be concluded that yeasts act through prebiotic rather than probiotic effects.

\section{ACKNOWLEDGMENTS}

The authors are grateful to G. Becker, M. Burmester, U. Dringenberg, and K. Hansen for their skilled technical assistence. 


\section{REFERENCES}

Adams, A. L., B. Harris, H. H. van Horn, and C. J. Wilcox. 1995. Effects of varying forage types on milk production responses to whole cottenseed, tallow, and yeast. J. Dairy Sci. 78:573-581.

Adams, D. C., M. L. Galyean, H. E. Kiesling, J. D. Wallace, and M. D. Finker. 1981. Influence of viable yeast culture, sodium bicarbonate and monensin on liquid dilution rate, rumen fermentation and feedlot performance of growing steers and digestibility in lambs. J. Anim. Sci. 53:780-789.

Arambel, M. J., and B. A. Kent. 1990. Effect of yeast culture on nutrient digestibility and milk yield response in early-to midlactation dairy cows. J. Dairy Sci. 73:1560-1563.

Arcos-García, J. L., F. A. Castrejón, G. D. Mendoa, and E. P. PérezGavilán. 2000. Effect of two commercial yeast cultures with Saccharomyces cerevisiae on ruminal fermentation and digestion in sheep fed sugar cane tops. Livest. Prod. Sci. 63:153-157.

ATCC. 1990. American Type Culture Collection, Catalogue of Yeasts. 18 th ed. S. C. Jong, and M. J. Edwards, ed. American Type Culture Collection, Rockville, MD.

Brandt, M., and K. Rohr. 1981. Quantification of N-metabolism in the forestomachs of dairy cows. 1. Examination of microbial N with ${ }^{15} \mathrm{~N}$ as a marker. J. Anim. Physiol. Anim. Nutr. 46:39-48.

Broberg, G. 1957. Measurements of the redox potential in the rumen contents. III. Investigations into the effect of oxygen on the redox potential and quantitave in vitro determinations of the capacity of rumen contents to consume oxygen. Nord. Veterinarmed. 9:942-950.

Cabrera, E. J. I., M. G. D. Mendoza, I. E. Aranda, C. Garcia-Bojalil, G. R. Bárcena, and J. J. Ramos. 2000. Saccharomyces cerevisiae and nitrogenous supplementation in growing steers grazing tropical pastures. Anim. Feed Sci. Technol. 83:49-55.

Chademana, I., and N. W. Offer. 1990. The effect of dietary inclusion of yeast culture on digestion in the sheep. Anim. Prod. 50:483-489.

Czerkawski, J. W., and G. Breckenridge. 1977. Design and development of a long-term rumen simulation technique (RUSITEC). Br. J. Nutr. 38:371-384.

Czerucka, D., and P. Rampal. 2002. Experimental effects of Saccharomyces boulardii on diarrheal pathogens. Microbes Infect. 4:733-739.

Dann, H. M., J. R. Prockley, G. C. McCoy, M. F. Hutjens, and J. E. Garrett. 2000. Effects of yeast cultures (Saccharomyces cerevisiae) on prepartum intake and postpartum intake and milk production of Jersey cows. J. Dairy Sci. 83:123-127.

Dawson, K. A., K. E. Newman, and J. A. Boling. 1990. Effects of microbial supplements containing yeast and lactobacilli on roughage-fed ruminal microbial activities. J. Anim. Sci. 68:3392-3398.

Drennan, M. 1990. Effect of Yea Sacc1026 on feed intake and performance of finishing bulls. Page 495 in Supplement to the Proceedings of Alltech's 6th Annual Symposium. Alltech Technical Publications, Nicholasville, KY.

Fallon, R. J., and F. J. Harte. 1987. The effect of yeasts culture inclusion in the concentrate diet on calf performance. J. Dairy Sci. 70 (Suppl.):119. (Abstr.)

Fiems, L. O., B. G. Cottyn, L. Dussert, and J. M. Vanacker. 1993. Effect of a viable yeast culture on digestibility and rumen fermentation in sheep fed different types of diets. Reprod. Nutr. Dev. $33: 43-49$.

Fleet, G. H. 1991. Cell walls. Pages 199-277 in The Yeasts. Vol. 14 A. H. Rose and J. S. Harrison, ed. Academic Press, New York, NY.

Garcia, C. C. G., M. G. D. Mendoza, M. S. Gonzales, P. M. Cobos, C. M. E. Ortega, and L. R. Ramirez. 2000. Effect of a yeast culture (Saccharomyces cerevisiae) and monensin on ruminal fermentation and digestion in sheep. Anim. Feed Sci. Technol. 83:165-170.

Harris, B., and R. Lobo. 1988. Feeding yeast culture to lactating dairy cows. J. Dairy Sci. 71 (Suppl. 1):276. (Abstr.)

Harris, B., and D. W. Webb. 1990. The effect of feeding a concentrate yeast culture to lactating dairy cows. J. Dairy Sci. 73(Suppl. 1):266. (Abstr.)
Harrison, G. A., R. W. Hemken, K. A. Dawson, R. J. Harmon, K. E. Newman, and M. C. Morehead. 1987. Yeast culture supplement in diets of lactating cows. I. Effects on rumen fermentation patterns and microbial populations. J. Dairy Sci. 70(Suppl. 1):342.(Abstr.)

Hughes, J. 1988. The effect of high strength yeast culture in diets of early-weaned calves. Anim. Prod. 46:526.

Klis, F. M. 1994. Review: Cell wall assembly in yeast. Yeast 10:851-869.

Kumar, U., V. K. Sareen, and S. Singh. 1994. Effect of Saccharomyces cerevisiae yeast culture supplement on ruminal metabolism in buffalo calves given concentrate diet. Anim. Prod. 59:209-215.

Kung, L., Jr., E. M. Kreck, and R. S. Tung. 1997. Effects of a live yeast culture and enzymes on in vitro ruminal fermentation and milk production of dairy cows. J. Dairy Sci. 80:2045-2051.

Miller-Webster, T., W. H. Hoover, M. Holt, and J. E. Nocek. 2002. Influence of yeast culture on ruminal microbial metabolism in continuous culture. J. Dairy Sci. 85:2009-2014.

Mishra, M., F. A. Martz, R. W. Stanley, H. P. Johnson, J. R. Campbell, and E. Hildebrand. 1970. Effect of diet and ambient temperaturehumidity on ruminal $\mathrm{pH}$, oxidation reduction potential, ammonia and lactic acid in lactating cows. J. Anim. Sci. 30:1023-1028.

Moukadiri, I., J. Armero, A. Abad, R. Sentandreu, and J. Zueco. 1997. Identification of a mannoprotein present in the inner layer of the cell wall of Saccharomyces cerevisiae. J. Bacteriol. 179:2154-2162.

Newbold, C. J. 1995. Microbial feed additives for ruminants. Page 259 in Biotechnology in Animal Feeds and Animal Feeding. R. J. Wallace and A. Chesson, ed. VCH, Weinheim, Germany.

Newbold, C. J., F. M. McIntosh, and R. J. Wallace. 1998. Changes in the microbial population of a rumen simulating fermenter in response to yeast culture. Can. J. Anim. Sci. 78:241-244.

Newbold, C. J., R. J. Wallace, X. B. Chen, and F. M. McIntosh. 1995. Different strains of Saccharomyces cerevisiae differ in their effects on ruminal bacterial nummers in vitro and in sheep. J. Anim. Sci. 73:1811-1818.

Newman, K. E., and P. Spring. 1993. A comparison of two different strains of yeast in their ability to alter ruminal and caecal fermentations. J. Anim. Sci. 71(Suppl. 1):289. (Abstr.)

Nolan, J. V., and R. A. Leng. 1983. Nitrogen metabolism in the rumen and its measurement. Pages 43-65 in Nuclear Techniques for Assessing and Improving Ruminant Feeds. IAEA Publishing Series, International Atomic Energy Agency, Vienna, Austria.

Orskov, E. R. and R. W. Hemken. 1967. Effect of ethanol infusion on milk fat content and composition and volatile fatty acids in the rumen liquor. J. Dairy Sci. 50:692-695.

Phillips, W. A., and D. L. von Tungeln. 1985. The effects of yeast culture on the post stress performance of feeder calves. Nutr. Rep. Int. 32:287-293.

Piva, G., S. Belladonna, G. Fusconi, and F. Sicbaldi. 1993. Effects yeast on dairy cow performance, ruminal fermentation, blood components, and milk manufacturing properties. J. Dairy Sci. 76:2717-2722

Pradhan, K., and R. W. Hemken. 1970. Utilization of ethanol and effect on fatty acid patterns in ruminants. J. Dairy Sci. 53:1739-1746.

Schroeder, B., C. Winkler, K. Failing, and G. Breves. 2004. Studies on the time-course of the effects of the probiotic yeast Saccharomyces boulardii on electrolyte transport in pig jejunum. Dig. Dis. Sci. 49:1311-1317.

Stuck, K., K. Faul, S. Hylla, J. Stein, and G. Breves. 1995. The application of a semi-continuous colon simulation technique (COSITEC) for studying the effects of clindamycin on microbial hindgut metabolism. Z. Gastroenterol. 33:241-246.

Wallace, R. J. 1994. Ruminal microbiology, biotechnology and ruminant nutrition: Progress and problems. J. Anim. Sci. 72:29923003.

Williams, P. E. W., C. A. G. Tait, G. M. Innes, and C. J. Newbold. 1991. Effects of the inclusion of yeast culture (Saccharomyces cerevisiae plus growth medium) in the diet of dairy cows on milk yield and forage degradation and fermentation patterns in the rumen of steers. J. Anim. Sci. 69:3016-3026. 